\title{
CINCO DIATRIBES DE EPICTETO SOBRE RAZÃO E LOUCURA
}

\author{
Tradução e apresentação por Aldo Dinucci ${ }^{1}$ \\ Universidade Federal de Sergipe (UFS) \\ (D) https://orcid.org/0000-0002-5854-4057
}

Epicteto, um dos grandes nomes do Estoicismo Imperial, entre os quais se incluem Sêneca, Musônio Rufo e Marco Aurélio, nasceu no ano 55, em Hierápolis, na Frígia, e morreu por volta de 135, em Nicópolis, antiga cidade localizada na entrada do Golfo Ambraciano, no Épiro. Filho de uma serva, recebeu um nome que era comumente dado a servos na Antiguidade e que significa 'adquirido' (epiktetos). Epicteto mesmo nada escreveu. Tal tarefa coube a Lúcio Flávio Arriano Xenofonte, cidadão romano de origem grega, que compilou (possivelmente com auxílio da taquigrafia) suas aulas em oito livros (As Diatribes de Epicteto), dos quais quatro sobrevivem, e constituiu o Encheirídion de Epicteto, um breviário de princípios morais epicteteanos.

Apresentaremos aqui nossa tradução de cinco diatribes do livro 1 das Diatribes de Epicteto: 1.12, 1.17, 1.21, 1.22, 1.27.

$\mathrm{Na}$ diatribe 1.12, intitulada "Sobre a satisfação", Epicteto menciona diversas teses sobre os Deuses ${ }^{2}$ disponíveis na Antiguidade: que existem; que não existem; que existem, mas não se ocupam com os homens; que existem e se ocupam com os homens nas coisas gerais; que existem e se ocupam com os homens nas coisas particulares (Diss. 1.12.1-2). Epicteto acaba por optar por essas duas últimas ${ }^{3}$, notando que elas estão de acordo com a concepção do homem justo que segue a natureza (a divindade máxima, para o estoicismo), pois, pensa nosso estoico, como o home justo poderia seguir a natureza se esta não existisse?

Portanto, o <homem > bom e justo, tendo considerado em sua inteligência todas essas coisas, segue aquele que administra a totalidade, do mesmo modo que os cidadãos <seguem> a lei da cidade-estado. (Diss. 1.12.7-8)

Epicteto decide-se, portanto, pelas teses compatíveis com o

\footnotetext{
${ }^{1}$ Doutor em filosofia e professor da Universidade Federal de Sergipe (UFS), Sergipe Brasil. Pesquisador em produtividade do CNPQ.

${ }^{2}$ Epicteto refere-se sucessivamente a Deus, a Zeus, aos Deus e à Natureza como à mesma coisa. Optamos por usar esses termos com as primeiras letras maiúsculas em razão do teísmo que cremos combinar-se com o panteísmo em Epicteto, indo além do panteísmo do estoicismo anterior a ele. Quanto a isso, cf. Braicovich, 2012.

${ }^{3}$ Deixaremos para outro trabalho avaliar a qual delas Epicteto finalmente se filia.
} 
estoicismo. Notem que ele não demonstra tais teses, mas se limita a mostrar que as quatro primeiras são incompatíveis com a doutrina do Pórtico. Epicteto desenvolve as teses teológicas que já anuncia em outras diatribes do livro 1: as diatribes 1.3 e 1.9 tratam da tese segundo a qual Deus é pai de todos os homens; as diatribes 1.6 e 1.16 tratam da Providência; a diatribe 1.13, intitulada "Como fazer cada coisa de modo agradável aos Deuses", aborda a questão da piedade; a diatribe 1.14 trata da tese da onipresença divina $^{4}$.

Epicteto lida, a seguir, com a questão de como seguir a divina administração e, ao mesmo tempo, ser livre (Diss. 1.12.8). Observando que é livre aquele para quem as coisas acontecem segundo sua escolha e sem impedimento, acrescenta que liberdade não é o mesmo que insanidade, pois "loucura e liberdade não caminham na mesma direção" (Diss. 1.12.9-10). Querer que tudo que se queira ocorra é loucura, observa Epicteto, pois o que se quer tanto não pode ser bom quanto pode ser a pior das coisas (Diss. 1.12.11-12).

Epicteto anuncia aí um dos principais pontos de sua doutrina, que é também o carro-chefe do estoicismo em geral: seguir a natureza. Em Epicteto, seguir a natureza, além de seguir a razão, é também seguir os acontecimentos tais como são propostos por Deus:

Ser instruído, porém, é aprender a desejar cada coisa como acontece. E como acontece? Como ordenou aquele que ordena. Ordenou haver verão e inverno, abundância e escassez, excelência e vício, e todas as contrariedades tais para a harmonia da totalidade. E deu, a cada um de nós corpo, partes do corpo, posses e companheiros. (Diss. 1.12.15-16)

Instruir-se, para Epicteto, é justamente aprender a seguir a totalidade (Diss. 1.12.16). Esse tema é belamente sintetizado no Encheiridion:

Não busques que os acontecimentos aconteçam como queres, mas quere que aconteçam como acontecem, e tua vida terá um curso sereno. (Epict. Ench. 8)

A partir dessa perspectiva, é preciso lidar com os homens, permitindo que "eles façam o que lhes pareça <bom> e nos mantenhamos igualmente segundo a natureza" (Diss. 1.12.19). Resta àqueles que assim não agem lamentar-se e contrariar-se (Diss. 1.12.22 ss.).

Na diatribe 1.20, intitulada "Acerca da razão - como ela contempla a si mesma", Epicteto retoma a tese do papel central da razão no ser humano, tema já delineado em Diss. 1.1. Em Diss. 1.20.5-7, nosso estoico reitera a tese de que a razão nos foi dada para o uso correto das representações

\footnotetext{
${ }^{4}$ Para detalhes sobre as doutrinas expostas por Epicteto, cf. DINUCCI. "Epicteto: seis diatribes teológicas". IN: Anais de Filosofia Clássica (Online), v. 8, p. 101, 2016.
} 
(phantasiai), sendo "a principal e primeira obra do filósofo $<\ldots>$ avaliar $^{5} \mathrm{e}$ distinguir as representações, e não aceitar nenhuma que seja reprovada".

Epicteto observa, entretanto, que poucos dão importância à capacidade diretriz (hegemonikon, a humana razão), pois o erro aí não é tão evidente quanto, por exemplo, no caso de distinguir entre o dinheiro verdadeiro e falso. Porém, a capacidade diretriz é justamente a que nos é dada para distinguir entre o bem e o mal, o certo e o errado (Diss. 1.20.5$11)$.

Na diatribe 1.17, intitulada "Que a lógica é necessária", mais uma vez destacando o papel central da razão, Epicteto afirma que a razão é o que articula e perfaz todas as coisas, pelo que é articulada por si mesma e não por outra coisa (Diss. 1.17.1-3). Eis a razão, segundo Epicteto, de os estoicos terem colocado em primeiro lugar o estudo da lógica, pois é esta que fornece à humana razão um critério de distinção entre o verdadeiro e o falso (Diss. 1.20.5-10).

A seguir, Epicteto reitera sua tese de que a filosofia é não somente uma atividade teórica, mas que é preciso perfazê-la através da aplicação das teorias à prática (Diss. 1.20.13-19). Epicteto belamente sintetiza essas reflexões no capítulo 49 do Encheiridion:

Quando alguém se crê merecedor de reverência por ser capaz de compreender e interpretar os livros de Crisipo, diz para ti mesmo: "Se Crisipo não escreveu de modo obscuro, ele não tem pelo que se crer merecedor de reverência". Mas o que eu desejo? Conhecer a natureza e segui-la. Busco então quem a interpreta. Ouvindo que é Crisipo, vou a ele. Mas não compreendo seus escritos. Busco então quem os interpreta - até aí, absolutamente nada há que mereça reverência. Quando eu acho o intérprete, resta-me fazer uso das coisas prescritas unicamente isso é digno de reverência. Ora, se admiro o próprio <ato de> interpretar, que outra coisa me torno senão gramático ao invés de filósofo? Com a diferença que, no lugar de Homero, interpreto Crisipo. Então, quando alguém me disser "Interpreta algo de Crisipo para mim", sobretudo enrubescerei quando não for capaz de exibir ações semelhantes às palavras e condizentes <com elas>. (Epict. Ench. 49)

A brevíssima diatribe 1.21 trata do desejo, comum entre os estudiosos de filosofia, de ser admirado pelos demais (Epict. Diss. 1.21.1-3). Após destacar que o em um ser humano que se dedica à filosofia deve seguir a natureza e utilizar as funções da capacidade de escolha segundo esta mesma natureza, Epicteto observa que a busca pela admiração alheia está em contradição com isso, já que é busca por algo externo. Como são ditos "loucos" os que ignoram as coisas que estão sob seu encargo (as coisas relacionadas à capacidade de escolha) e se dedicam às coisas que não estão

\footnotetext{
${ }^{5}$ Dokimazein.
} 
sob seu encargo (que são externas), buscar a admiração destes é justamente buscar a admiração dos loucos e, Epicteto não menciona, mas acrescentaremos, fazer a si mesmo de louco, já que, ao invés de concentrarse e dar valor unicamente às coisas sob seu encargo, o pretenso filósofo se desvia e passa a dar valor às coisas que não estão sob seu encargo.

$\mathrm{Na}$ diatribe 1.22, intitulada "Sobre as pré-noções", Epicteto realiza uma discussão sobre essa concepção estoica. Não focalizaremos aqui esse conceito, mas o que vem a seguir na discussão. Nosso estoico observa que o exame das pré-noções, pelo qual se aprende a ajustá-las "às substâncias particulares de modo adequado à natureza e, além disso, distinguir, entre as coisas, as que são encargo nosso e as que não são" (Epict. Diss. 1.22.9), pode levar a resultados aparentemente paradoxais. De acordo com o teorema acerca das coisas que estão sob nosso encargo e das coisas que não estão sob nosso encargo, que Epicteto anuncia em Diss. 1.1 e em Ench. 1, apenas as primeiras, aquelas relacionadas às funções da faculdade de escolha, podem ser ditas propriamente boas ou más, enquanto as demais não o podem. Isso porque as coisas externas são materiais sobre os quais trabalha a capacidade de escolha: se esta lidar de modo inadequado com certa coisa externa, ela fará mau uso desta coisa externa e causará dano a si mesma. Um exemplo simples: uma mera faca de cozinha pode se tornar uma arma mortal para um marido ciumento que, esfaqueando sua esposa, se tornará por isso um assassino. A faca não é por si mesma boa ou má - bom ou mau será o uso que se fará dela, e esse uso dependerá da qualidade da capacidade de escolha envolvida na ação e das opiniões sobre as quais esta se ampara para efetuar sua decisão. Entretanto, observa Epicteto na diatribe em questão, se essa reflexão apresentada sem as devidas explicações a um leigo, por exemplo, dizendo-lhe que a pátria, a saúde, o corpo e a vida não são por si mesmos bens para alguém sem instrução estoica, isto soará como algo insuportável e absurdo (Epict. Diss. 1.22.11-12) e fará o aprendiz de filosofia e o filósofo parecerem loucos diante dos demais. E, Epicteto salienta, não devemos nos importar em parecermos loucos (como vimos acima, isso seria justamente dar valor a algo externo), mas simplesmente assentir divertidamente à acusação. Para entendermos isso, leiamos o delicioso diálogo final desta diatribe abaixo:

Algum ancião grisalho, usando muitos anéis de ouro, chegará. Então, balançando a cabeça, dirá: "Escuta, fillho, é preciso filosofar, mas é preciso também ter cérebro ${ }^{6}$. Essas coisas são tolices! (19) Tu aprendes silogismos dos filósofos, mas sabes melhor que eles o que é preciso fazer". (20) "Homem, por que me repreendes se sei?" (21) O que digo para esse prisioneiro? Se eu silencio, ele explode. Que é preciso dizer senão "Perdoame como àqueles que amas. Estou fora de $\mathrm{mim}^{7}$ ! Estou louco!"

${ }^{6}$ Dei kai enkephalou echein. Poderíamos traduzir também por: "É preciso ter miolos!"

${ }^{7}$ Ouk eimi emautou: literalmente "Não sou de mim mesmo". Em grego, há uma expressão 
$\mathrm{Na}$ diatribe $1.27^{8}$, Epicteto começa por distinguir os modos de perceber. Segundo nosso estoico, quatro são os modos como percebemos: ou algo parece ser o que é, ou parece não ser o que não é, ou parece ser o que não é, ou parece não ser o que é. Em todos esses casos, acertar o alvo é próprio de um homem preparado. Caso algo perturbe a mira, é preciso remediar tal perturbação, seja esta (I) sofismas de pirrônicos ou acadêmicos, (II) a persuasividade das coisas que, não sendo boas ou más, parecem boas ou más ou (III) um hábito (Epict. Diss. 1.27.1-2). Epicteto menciona rapidamente os modos de não fracassar diante de cada uma dessas coisas. O remédio para (I) sofismas é saber lógica e ser exercitado nela. O remédio para (II) a persuasividade das coisas é ter à mão pré-noções claras. O remédio para (III) um mau hábito é um hábito contrário. Na terceira parte, Epicteto trata desses remédios numa determinada ordem que é a da vida real, na qual vamos da persuasividade das coisas ao hábito e à lógica (Epict. Diss. 1.27.3-6).

Assim, quando a morte parecer um mal (o que se inclui no terceiro tipo de percepção, sendo esta uma percepção que não acertou o alvo por ter sua mira perturbada pela persuasividade da morte que, não sendo um bem ou um mal, passa por um mal), é preciso ter à mão as pré-noções de que convém evitar o mal e que a morte é necessária. Mas mesmo sabendo claramente que a morte não é um mal (ou seja, mesmo já tendo escapado da persuasividade das coisas), é possível, por força do hábito, continuar temendo e lamentando a morte.

Assim, o homem preparado é aquele que vence a persuasividade das coisas, estabelece um hábito novo e está preparado para lidar com as objeções argumentativas que realmente importam, descartando aquelas que não têm relação com a obtenção da sabedoria e são meros sofismas.

Em seguida, Epicteto retoma ao tema já abordado na diatribe 1.12: a origem do sofrimento é querer algo e não obter (Epict. Diss. 1.27.11). Como consequência desse querer torto, além da infelicidade já apontada em Diss. 1.12 , há o despertar da agressividade em relação aos que são vistos como obstáculos ao querer (Epict. Diss. 1.27.12). Essa será a causa da impiedade, pois por natureza o ser humano não suporta se ver apartado do bem e, ao projetar o bem em algo externo e ao ver esse "bem" impedido, voltar-se-á contra o impedimento. Assim, se Zeus é visto como impedimento para algo que se quer, blasfema-se contra ele (Epict. Diss. 1.27.12-13).

Nesse contexto, Epicteto menciona os céticos e os acadêmicos ${ }^{9}$. O

\footnotetext{
semelhante: En emautou einai ("Sou senhor de mim mesmo").

${ }^{8}$ Agradecemos a ajuda do Dr. Alexandre Cabeceiras na análise dessa difícil diatribe, a quem atribuímos a formalização aqui apresentada.

${ }^{9}$ Para mais detalhes sobre o diálogo entre Epicteto e os céticos, cf. DINUCCI \& BRITO, 2014.
} 
texto é de difícil leitura, mas como se relaciona à questão da razão e da loucura, alvo dessa apresentação, o analisaremos em detalhe:

Que venham e nos encontrem o pirrônico e o acadêmico. Eu, com efeito, por minha parte, não tenho tempo livre para essas coisas, nem posso defender o senso comum. Se também eu tivesse uma demanda sobre um diminuto terreno, requereria outro para ser meu advogado. (Epict. Diss. 1.27.15-16)

Nosso estoico, com essas palavras, pelas quais acusa os pirrônicos e os acadêmicos de serem maus advogados, isto é, de argumentarem mal (o que significa que usam sofismas em sua argumentação, como ele já dissera no princípio desta diatribe), anuncia o tema que tocará a seguir, a questão de como se formam as percepções, se da parte ao todo ou se do todo à parte. Epicteto curiosamente confessa que não tem uma resposta para essa questão: ambas as possibilidades de resposta o confundem. Entretanto, a solução dessa dificuldade não o impede de viver e fazer uso adequado das percepções:

Que eu e tu não sejamos a mesma pessoa, eu sei muitíssimo bem. Como isso? Quando quero engolir um pedaço de pão, jamais o ponho aí, mas aqui. Quando quero pegar um pão, jamais pego a vassoura, mas sempre vou em direção ao pão como que para um alvo. Vós mesmos, que suprimis as percepções, fazeis algo diferente? Qual de vós vai ao moinho quando quer ir ao banho público? (Epict. Diss. 1.27.17-19)

Epicteto observa que, para questões práticas, a dificuldade teórica não cumpre qualquer papel e que mesmo os céticos (tanto os pirrônicos quanto os acadêmicos) se guiam pela percepção. O que vem a seguir, porém, é surpreendente:

E então? Não é preciso agarrar-se a estas coisas na medida de nossa capacidade: velar pelo senso comum, fortificar-nos contra o que é contra ele? E quem diz o contrário? Porém, <ocupa-se disso> quem tem capacidade e tempo livre. Aquele que treme, que se agita e que tem o coração em pedaços precisa ter tempo para outra coisa. (Epict. Diss. 1.27.20 ss.)

Epicteto menciona um dos critérios céticos, que é a observância do senso comum, e parece concordar com ele, embora notando que essa observância depende de capacidade e tempo livre, o que não é o seu caso, pois está feito em pedaços e precisa tempo para outra atividade. $\mathrm{O}$ que ele estará querendo dizer com isso? O que segue é apenas uma conjectura, dentro do espírito do tema da razão e da loucura desta apresentação. Epicteto estaria dizendo que, sim, as questões teóricas sobre a percepção são relevantes, mas que nem para aqueles que as fazem elas constituem impedimento para que se guiem por elas, pelo que a cética observância do 
senso-comum e, acrescentemos aqui, a atividade teórica que ela supõe, qual seja, o infindável exame de todas as teorias em busca de diafonia e mútua refutação, caberia para alguém com capacidade e tempo livre, duas coisas que nosso filósofo diz não possuir por "ter o coração aos pedaços". Parecenos aqui desvelar-se uma socrática confissão de ignorância. Pois se, como vimos acima, é loucura querer que aconteça tudo o que se quer que aconteça, revoltando-se contra a natureza, ignorar a faculdade diretriz e o bom uso das representações, dar valor às coisas externas e não dar valor às coisas internas, que estão sob nosso encargo, e se é sabedoria querer que aconteça tudo o que acontece, seguindo a Natureza, cuidar da faculdade diretriz e fazer bom uso das representações, não dar valor às coisas externas e dar valor às coisas internas, que estão sob nosso encargo, a passagem da loucura para a sabedoria pressupõe reconhecer seu próprio estado de insanidade para que a partir disso seja possível a aplicação dos remédios mencionados ao princípio da diatribe 1.27: o uso da lógica contra os sofismas, dispor de pré-noções claras e impor-se bons hábitos em substituição aos maus. E não há tempo a perder com outras coisas, pois, como diz Epicteto em fragmento que nos foi transmitido por Marco Aurélio (11.38) relativo à atividade da filosofia: "A luta não é por algo banal, mas por ficar louco ou não" $"$.

Realizamos a tradução diretamente a partir do texto grego estabelecido por Schenkl (1916) e cotejamos nosso trabalho com as melhores traduções disponíveis das Diatribes de Epicteto, dando especial atenção à de Souilhé (1962), à de George Long (1877) e à de Dobbin (2008).

\section{Diatribe 1.12 - Sobre a satisfação ${ }^{11}$ :}

(1) Sobre os Deuses, alguns dizem não existir o divino ${ }^{12}$; outros dizem existir, porém ocioso ${ }^{13}$, descuidado ${ }^{14}$ e imprevidente ${ }^{15}$; (2) em terceiro lugar, há os que dizem existir e ser previdente, mas quanto às coisas grandes e celestiais e não quanto às terrenas ${ }^{16}$; em quarto lugar, há os que dizem <serem previdentes> também em relação às coisas terrenas e às

\footnotetext{
${ }^{10}$ Fragmento 168 .

${ }^{11}$ Euarestesis:

12 Esses são os ateístas, como Diágoras de Melos, Teodoro de Cirene, Crítias de Atenas, entre outros (cf. Sexto Empírico, Esboços pirrônicos, 3.218; Adversus Mathematicos, 9.507; Cícero, De natura deorum, 1.2).

${ }_{13}$ Argos. Esse segundo grupo engloba os epicuristas (Cf. DL 10.139).

${ }^{14}$ Ameles.

${ }^{15}$ Pronoein medenos.

${ }^{16}$ Esse terceiro grupo provavelmente engloba os peripatéticos. Como nos informa Dobbin (1998, p. 139), no período imperial era essa a visão que se tinha sobre o estagirita, que a expressa em Metafísica 12.6-10, embora pareça contradizê-la em Ética Nicomaqueia $1179^{a}$ 24-5 (Cf. Diógenes Laércio 5.32; Sexto, Esboços pirrônicos 3.218).
} 
humanas, mas só <em relação às> gerais e não às próprias ${ }^{17}$ de cada um ${ }^{18}$; (3) em quinto lugar ${ }^{19}$, há aqueles, entre os quais <se contam> também Odisseu e Sócrates, que dizem "Movendo-me, não te escapo" ${ }^{20}$. (4) Desse modo, antes de tudo o mais, é necessário considerar, sobre cada uma dessas <posições>, se são ditas de modo verdadeiro ou não. (5) Pois se os Deuses não existem, como será o <nosso> fim seguir os Deuses ${ }^{21}$ ? Porém, se existem, de ninguém cuidando, assim também como será verdadeiro <ser nosso fim segui-los>? (6) Mas se existem e cuidam, e nenhuma comunicação há entre os homens e eles e, por Zeus, também comigo, como ainda isso será verdadeiro? (7) Portanto, o <homem> bom e justo, tendo considerado em sua inteligência todas essas coisas, segue aquele que administra a totalidade, do mesmo modo que os cidadãos <seguem> a lei da cidade-estado. (8) Aquele que se instruiu deve conduzir-se a respeito da instrução com o seguinte propósito ${ }^{22}$ : como eu poderia seguir os Deuses em toda circunstância? E como eu poderia me comprazer $^{23}$ com a divina administração? E como eu poderia me tornar livre? (9) Pois é livre aquele a quem todas as coisas acontecem segundo a escolha e a quem nada faz impedimento. (10) E então? A liberdade é insanidade ${ }^{24}$ ? De modo algum! Loucura $^{25}$ e liberdade não caminham na mesma direção. (11) "Eu, porém, desejo que tudo que me pareça <bom> ocorra, e de qualquer modo que me pareça <bom>”. (12) Estás louco, deliras ${ }^{26}$. Não percebes que a liberdade é algo bom e valioso ${ }^{27}$. Desejar que ocorresse não importa o que me pareça $<$ bom ${ }^{28}$, isso é possível não só não ser bom, mas também <é possível ser>

\footnotetext{
${ }^{17}$ Kat'idian.

${ }^{18}$ Esse quarto grupo engloba estoicos como Sêneca (Cartas a Lucílio, 95.50) e ecléticos como Cícero (De natura deorum, 2.167). Entre os estoicos, sempre foi uma posição heterodoxa.

${ }^{19}$ Esse quinto grupo engloba Sócrates (Xenofonte, Memoráveis, 1.1.19; 1.4.18; 4.3.12), além de ser a doutrina ortodoxa estoica (Cf. Cícero, De Natura Deorum, 1.1.2) e aquela de Epicteto.

${ }^{20}$ Homero, Ilíada, 10.278. Tradução literal. O verso faz parte da oração de Ulisses a Atena, que apresento a seguir na tradução de Carlos Alberto Nunes:

Ouve-me filha de Zeus poderoso que em todas as minhas

dificuldades me assistes a quem não se ocultam meus passos

Palas Atena! Ora mais do que nunca propícia me ajuda.

Dá que possamos cobertos de glória voltar para as naves

após grande feito acabarmos que há de lembrar sempre os Teucros.

${ }^{21}$ Pos esti telos hepesthai theois; - cf. Marco Aurélio 10.11.

${ }^{22}$ Epibole: concepção, noção, propósito.

${ }^{23}$ Kai pos an euarestoien tei theiai dioikesei.

${ }^{24}$ Aponoia.

${ }^{25}$ Mania.

${ }^{26}$ Paraphroneis: $2^{\mathrm{a}}$ do singular do presente indicativo ativo de paraphroneo.

27 Axiologos: digno de menção, notável. Escolhi "valiosa" pela relação do termo com o conceito de axia ("valor"), central em Epicteto.

${ }^{28}$ To d'os etychen me boulesthai ta os etychen doxanta ginesthai: nessa passagem vertemos tynchano por "acontecer" e gignomai por "ocorrer" (e não, como habitualmente fazemos,
} 
a pior de todas as coisas. (13) Como agimos em relação às letras? Desejo escrever como quiser o nome "Bíon"? Não. Mas aprendo a querer escrever como é preciso. E sobre a música? Do mesmo modo. (14) E, em geral, onde há alguma arte ou ciência. Caso contrário, se cada coisa se ajustasse aos desejos, nenhum valor teria saber algo. (15) Então é só aí, sobre o que é maior e principal, a liberdade, que me é permitido desejar ao acaso? De modo algum. Ser instruído, porém, é aprender a desejar cada coisa como acontece $^{29}$. E como acontece? Como ordenou aquele que ordena ${ }^{30}$. (16) Ordenou haver verão e inverno, abundância e escassez, excelência e vício, e todas as contrariedades tais para a harmonia ${ }^{31}$ da totalidade. E deu a cada um de nós corpo, partes do corpo, posses e companheiros.

(17) Assim, lembrando-nos dessa disposição, é preciso caminhar para a instrução, não para alterar as hipóteses ${ }^{32}$ (já que isso nem nos é dado, nem é o melhor), mas para que, sendo como são e como foram naturalmente geradas as coisas ao nosso redor, tenhamos a inteligência a respeito delas em conformidade $^{33}$ com os acontecimentos. (18) E então? É possível escapar dos homens? E como isso seria possível? Podemos, estando com eles, alterá-los? E quem nos deu <esse poder>? (19) Então o que nos resta ou que meio se descobre para lidar com eles? Um meio tal pelo qual eles façam o que lhes pareça <bom> e nos mantenhamos igualmente segundo a natureza. (20) Porém, tu és impaciente ${ }^{34}$ e difícil de $\operatorname{agradar}^{35}$ : (21) se estás só, chamas isso de solidão ${ }^{36}$; se <estás> com outros homens, chama-os de insidiosos e ladrões; e censuras também teus próprios pais, teus filhos, teus irmãos e teus vizinhos. É preciso, ao estar só, chamar isso de repouso e liberdade e pensar-se como semelhante aos Deuses; mas, ao estar com os muitos, é preciso chamar isso não de tumulto ${ }^{37}$, nem confusão ${ }^{38}$, nem algo nauseante ${ }^{39}$, mas festa $^{40}$ e festival $^{41} \mathrm{e}$, assim, receber tudo com satisfação.

por "acontecer") para dar conta do jogo de palavras entre "desejar que aconteçam coisas que parecem boas" e "coisas que acontecem (calham) parecer boas ocorrer". Arriano inspirou-se nessa passagem para compor o capítulo 8 do Encheiridion.

${ }^{29}$ Cf. Marcos Aurélio 4.23.

${ }^{30}$ Os dietaxen auta ho diatasson. O verbo diatasso significa primariamente "nomear, ordenar, dispor".

${ }^{31}$ Symphonia. Cf. Aulo Gélio, 4.1 (em que Gélio cita passo do Da providência, de Crisipo: "Nada é mais tolo que as opiniões daqueles que pensam que o bem poderia existir sem o mal"); Simplício, Comentário ao Encheiridion de Epicteto, 13.8; 34.27; Ench. 27.

${ }^{32}$ Hypotheseis. Georg Long traduz o termo por "constituition of things", conjecturando com o que vem a seguir. Entretanto, seguimos aqui Dobbin.

33 Synermosmenen: particípio perfeito passivo de synarmozo, que significa primariamente "combinar-se, conformar-se, encaixar-se".

${ }^{34}$ Atalaiporos: ou ainda "incapaz de suportar fadiga".

${ }^{35}$ Dysarestos: literalmente "descontente".

${ }^{36}$ Eremia.

${ }^{37}$ Ochlos: literalmente "multidão".

${ }^{38}$ Thorybos.

${ }^{39}$ Aedia. 
E qual é o castigo ${ }^{42}$ para os que não aceitam favoravelmente < tudo o que ocorre>? (22) Ser como são. Alguém está descontente por estar só? Esteja na solidão. Alguém está descontente com os pais? Seja mau filho e lamente. Está descontente com os filhos? Seja mau pai. (23) "Lança-o na prisão". Qual prisão? Aquela na qual ele está agora. Pois está <aí> contrariado $^{43}$. (24) Onde alguém está contrariado, aí para ele é a prisão. Portanto, Sócrates não estava na prisão, pois estava ali voluntariamente ${ }^{44}$. "Mas minha perna será mutilada!" Prisioneiro! Por uma minúscula perna ${ }^{45}$ acusas o Cosmos? Não a cederás voluntariamente pela totalidade? Não te separarás dela? Sendo grato, não a devolverás a quem a deu a ti? (25) Irritarte-ás ${ }^{46}$ e ficarás descontente com as coisas que foram dispostas por Deus, coisas que ele, através das Moiras $^{47}$, presentes e fiando ${ }^{48}$ a tua gênese, definiu e dispôs? (26) Não sabes que tu és pequena parte em relação à totalidade $?^{49}$ Isso segundo o corpo, porque certamente segundo a razão não és inferior nem menor que os Deuses ${ }^{50}$ : pois a grandeza da razão não é julgada pelo tamanho, nem pela altura, mas pelas opiniões.

(27) Não desejas pôr teu bem aí, nas coisas segundo as quais <és> igual aos Deuses? (28) "Sou um infeliz: tenho tal pai e tal mãe!” E então? Éte dado, antecipando-te, escolhê-los e dizer: "Que tal e qual se encontrem a tal hora para que eu nasça". Não te é dado. (29) Porém, é preciso que teus pais preexistam e, desse modo, tu sejas gerado. (30) E partir de quais <pais>? Destes, tais como são. E então? Tais sendo eles, nenhum meio te é dado? Também, se ignoras para o que tens a capacidade da visão, és desafortunado $^{51}$ e infeliz ${ }^{52}$ se fechas os olhos diante das cores apresentadas a ti. Entretanto, se ignoras que possuis grandeza de alma $^{53}$ e a mais elevada nobreza $^{54}$ em relação a cada uma ${ }^{55}$ dessas coisas, não és ainda mais

\footnotetext{
${ }^{40}$ Eorte.

${ }^{41}$ Panegyros.

${ }^{42}$ Kolasis.

${ }^{43}$ Akon gar esti.

${ }^{44}$ Ekon gar en.

${ }^{45}$ Skelydrion: diminutivo de skelos ("perna").

${ }^{46}$ Aganakteseis: segunda do singular do futuro indicativo de aganakteo.
}

${ }^{47}$ Segunda a mitologia grega, são as Moiras as três irmãs que literalmente teciam o destino de homens e Deuses. São elas Cloto (“a que fia”), Láquesis ("a que sorteia”) e Átropos ("a que corta" - e determina o fim da vida).

${ }^{48}$ Epiklothouson: particípio de epikloto, que significa primariamente atribuir. O verbo é comumente associado às Moiras, daí nossa tradução.

${ }^{49}$ Cf. Marcos Aurélio 2.4; Lucrécio 6.652: "Et quota pars homo sit terrai totius unus."

${ }^{50} \mathrm{De}$ acordo com os antigos, deuses e homens diferem apenas quanto ao poder (sendo os primeiros mais poderosos que os segundos) e ao tempo de vida (sendo os primeiros imortais e os segundos mortais).

${ }^{51}$ Dystyches.

52 Athlios.

${ }^{53}$ Megalopsychia.

${ }^{54}$ Gennaioteta: superlativo de gennaiotes (nobreza), de gennaios (nobre). 
desafortunado e infeliz? (31) São postas diante de ti coisas adequadas à força que possuis. Tu, contudo, neste momento, antes a pões de lado, quando é preciso tê-la desperta e atenta. (32) Não darás, ao invés disso, graças aos Deuses por te porem acima das quantas coisas que não fizeram sob teu encargo, mas te proclamarem somente responsável pelas sob teu encargo? (33) Não te puseram como responsável pelos teus pais nem pelos teus irmãos, nem pelo teu corpo, tuas posses, tua morte, tua vida. (34) Então pelo que te fizeram responsável? Somente pelo que é teu encargo: o uso das representações como é preciso ${ }^{56}$. (35) Então por que arrastas ${ }^{57}$ para ti mesmo essas coisas pelas quais não és responsável? Isso é causar ${ }^{58}$ problemas para si mesmo!

Diatribe 1.20 - Acerca da razão - como ela contempla a si mesma ${ }^{59}$ :

(1) Toda arte e toda capacidade contempla certas coisas em primeiro lugar ${ }^{60}$. (2) Desse modo, quando ela é também semelhante às coisas contempladas, necessariamente contempla a si mesma. (3) Porém, quando é de gênero diverso, não pode contemplar a si mesma. (4) Por exemplo, a arte do sapateiro lida com couros, mas distancia-se por completo da matéria dos couros. Por isso, não contempla a si mesma. A gramática, por sua vez, trata das palavras escritas. Ela é também palavra escrita? De modo algum. Por isso não é capaz de contemplar a si mesma. (5) Então para que recebemos da natureza a razão? Para usar as representações como é preciso. E a razão ela mesma, o que é? Um sistema <constituído> de representações de certa qualidade. Assim, por natureza, contempla a si mesma. (6) A sabedoria $^{61}$, por sua vez, nos foi dada para contemplar o que? Coisas boas, más e indiferentes. O que ela é? O bem. E a falta de sabedoria ${ }^{62}$ ? O mal. Vês que também necessariamente ela contempla tanto a si mesma quanto seu contrário? (7) Por isso a principal e primeira obra do filósofo é avaliar ${ }^{63}$ e distinguir as representações, e não aceitar nenhuma que seja reprovada.

(8) Vês, acerca da moeda corrente, que parece ser algo <importante>

55 Pros hekasta touton: Dobbin: "to deal with these things"; Georg Long: "for every event that may

happen".

${ }_{56}$ Chreseos hoias dei phantasion.

57 Epispais: presente indicativo ativo, $2^{\mathrm{a}}$ do singular de epispao, que significa primariamente "arrastar atrás de si".

58 Parechein é infinito presente ativo de parecho, que significa primariamente "fornecer", "suprir" e, derivativamente, "causar".

${ }^{59}$ Para a compreensão da diatribe como um todo, cf. Diss. 1 e 17.

${ }^{60}$ Pasa techne kai dynamis proegoumenon tinon esti theoretike. O termo proegoumena pode significar "premissas", "dados iniciais", "as coisas que precedem". Decidimos o sentido pela frase que vem a seguir.

${ }^{61}$ Phronesis.

${ }^{62}$ Aphrosyne.

${ }^{63}$ Dokimazein. 
em relação a nós, como também descobrimos a arte e quantos meios quem verifica a prata usa para avaliar a moeda corrente: a visão, o tato, o olfato e, por fim, a audição. (9) Lançando o denário, ele o testa pelo ruído, e não se contenta quando ouve o ruído uma única vez. Por muita atenção aplicada, músico se torna. (10) Assim, onde pensamos diferir o errar do não errar, aí também aplicamos muita atenção quanto a distinguir as coisas capazes de nos fazer incorrer em erro. (11) Porém, no caso da pobre capacidade diretriz, aceitamos toda representação bocejando e dormindo: pois a perda aí não é manifesta $^{64}$. (12) Então, quando desejares saber como és displicente sobre as coisas boas e más, e ansioso e apressado sobre as indiferentes, fixa tua atenção em tua atitude a respeito de tornar-te cego e ser enganado - e saberás que longe estás de como é preciso se dispor ${ }^{65}$ sobre as coisas boas e más.

- (13) Mas há precisão de muita preparação ${ }^{66}$, muito esforço e muito aprendizado.

- E então? Esperas que a melhor arte está para ser adquirida com pouco <esforço>? (14) Em verdade, o discurso principal dos filósofos é muitíssimo curto. Se quiseres sabê-lo, lê os escritos de Zenão ${ }^{67}$ e verás. (15) É, pois, longo dizer que "o fim é seguir os Deuses ${ }^{68}$ ? E que a substância do bem é usar as representações como é preciso"? (16) Diz: "Então o que é Deus e o que é a representação? E o que é a natureza particular ${ }^{69}$ e o que é a natureza do todo?" Agora, longo <tornou-se o discurso>.

(17) Assim, se Epicuro vier a nós e disser que é preciso que o bem esteja na carne, grande se torna <o discurso>, e é necessário aprender o que é o princípio diretor ${ }^{70}$ em nós, o que é o que pertence à substância ${ }^{71}$ e o substancial $^{72}$. Por que é verossímil que o bem do molusco não esteja na concha, mas o bem do homem esteja? (18) E tu mesmo, Epicuro, qual é a tua parte mais importante? O que em ti é o que deseja, o que investiga cada coisa? O que, sobre a própria carne, decide ${ }^{73}$ que ela é a parte principal? (19) Por que acendes a lâmpada? Por que penas por nós e escreves tantos livros? Para que nós não ignoremos a verdade? Quais de nós? O que somos

\footnotetext{
${ }^{64} \mathrm{O}$ verbo aqui é prospitno, que significa literalmente "entrar", “entrar em cena”. Souilhé traduz a frase por "tu sauras que tu es loin d'avoir les sentiments qui conviennent à l'égard des biens et des maux". Dobbin, por "and you will realize how far you are from feeling as you ought about things good and bad".

${ }^{65} \mathrm{O}$ verbo aqui é pascho, que significa literalmente "sofrer", "estar em estado passivo". Outra opção para a tradução do verbo na passagem seria "sujeitar-se".

${ }^{66}$ Paraskeue.

${ }^{67}$ De Cítio (cf. introdução).

${ }^{68}$ Cf. Diss. 1.12 .5

${ }^{69}$ Ti esti physis he epi merous kai ti esti physis he ton holon? Cf. Marco Aurélio 5.25; 6.5.

${ }^{70}$ To proegoumenon. Cf. Zenão de Cítio, 1.48 .

${ }^{71}$ Hypostatikon.

72 Ousiodes.

${ }^{73} \mathrm{O}$ verbo aqui é epikrino.
} 
em relação a ti? Portanto, longo torna-se o discurso.

\section{Diatribe 1.17 - Que a lógica é necessária:}

(1) Já que a razão ${ }^{74}$ é o que $\operatorname{articula~}^{75}$ e perfaz as demais coisas, 〈e〉 é preciso que ela mesma não seja desarticulada, pelo que ela seria articulada? (2) É, por conseguinte, evidente que é articulada ou por si mesma ou por outra coisa. Assim, certamente a razão é tal, ou haverá algo maior que ela, o que é impossível. (3) Pois se a razão for tal, quem, por sua vez, articulará aquela ${ }^{76}$ ? Se <a razão> articular a si mesma, esta ${ }^{77}$ também o pode. Se necessitarmos de outra, esse <processo> será infinito ${ }^{78}$ e incessante $^{79}$.

(4) "Sim! Urge, porém, antes tratar [...] $]^{80 ", ~ e ~[. . .] ~ s e m e l h a n t e s . ~ E n t a ̃ o ~}$ queres ouvir sobre essas coisas? Ouve. Mas se me disseres "Não sei se discorres de modo verdadeiro ou falso", e se eu disser uma palavra ambígua, e tu me disseres "Efetua a distinção ${ }^{81 ",}$ não mais te tolerarei e direi: "Antes disso algo urge". Pois penso que os estoicos põem em primeiro lugar o estudo da lógica em razão disso, do mesmo modo que, em relação à medição do tempo, colocamos em primeiro lugar a investigação da medida. (7) Se não especificarmos primeiro o que é um módio ${ }^{82}$ nem definirmos primeiro o que é uma balança, como seremos capazes de medir ou pesar algo? (8) Então, no caso presente, se não aprendermos nem compreendermos com exatidão o critério das demais coisas, o critério pelo qual as demais são aprendidas, poderemos compreender com exatidão ou aprender alguma delas? Como seria possível? (9) "Sim, mas o módio é de madeira e não dá frutos". (10) Porém é próprio para medir o trigo. "E a lógica não dá frutos". Vejamos isso também. Assim, ainda que alguém concedesse isso, basta <dizer> que <a lógica> é própria para distinguir ${ }^{83}$,

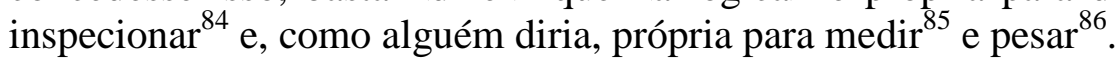

\footnotetext{
${ }^{74}$ Logos. Epicteto refere-se aqui à razão universal que governa o mundo.

75 Diarthron é particípio de diartheo, que significa primariamente "dividir por juntas", "articular".

${ }^{76}$ Ekeinon: acusativo singular de ekeinos ("aquele"). Epicteto transita do conceito de razão universal para o de razão particular de cada ser humano. Está, então, se referindo à capacidade racional de algum dos presentes, por meio de ato dêitico.

77 Houtos. O pronome "este". Epicteto está, agora, apontando ou para a própria cabeça ou para o próprio coração (os dois lugares onde os estoicos criam ser a sede da razão), designando, portanto, a sua própria razão individual.

${ }_{78}^{78}$ Apeiron.

${ }^{79}$ Akatalektos.

${ }^{80}$ Há aqui uma lacuna no texto. Dobbin e Georg Long põem aí "nossas opiniões".

${ }^{81}$ Diastixon: imperativo de diastizo (literalmente "distinguir com uma marca").

${ }^{82}$ Modios (modius em latim): medida romana de capacidade aproximadamente equivalente ao alqueire.

${ }^{83}$ Diakritika.

${ }^{84}$ Episkeptika.
} 
(11) Quem diz essas coisas? Apenas Crisipo, Zenão <de Cítio> e Cleanto? Antístenes não as diz? (12) Mas quem é que escreveu que "o princípio da instrução é a investigação dos nomes"? Sócrates não as diz? E sobre quem escreveu Xenofonte ${ }^{87}$, que <diz que> Sócrates começava pela investigação dos nomes, pelo que cada um significa?

(13) É isso algo grande e admirável ${ }^{88}$ : conhecer ou interpretar Crisipo? Quem diz isso? O que, porém, é admirável? Conhecer o propósito da Natureza ${ }^{89}$. (14) E então? Segues ${ }^{90}$ esse <propósito> por ti mesmo? E do que ainda tens precisão? Pois se é verdadeiro que todos os homens cometem faltas $^{91}$, e tu observas a verdade, agora te é necessário agir corretamente ${ }^{92}$. (15) Mas, por Zeus, não sigo <com minha razão> o propósito da natureza. Quem o interpreta? Dizem que é Crisipo. (16) Vou e perquiro ${ }^{93}$ o que diz esse intérprete da Natureza. Começo não entendendo o que ele diz, busco quem o interpreta. "Vai investigar <, diz o intérprete, > como isso é dito, como se em latim" "94. (17) Que lugar há para orgulho para quem interpreta? Nem, com justiça, para o próprio Crisipo há se só interpretar o propósito da natureza, mas não a seguir, quanto mais para quem o interpreta. (18) Não temos precisão de Crisipo por si mesmo senão para que sigamos ${ }^{95}$ a Natureza. Não temos necessidade do sacerdote oracular ${ }^{96}$ por si mesmo senão para que, através da observação dele, percebamos as coisas que estão por vir e os signos divinos. (19) Nem <temos precisão> das vísceras por si mesmas senão para que por meio delas seja expresso o signo. Nem admiramos o corvo ou a gralha, mas Deus, que envia signos por meio deles $^{97}$. (20) Vou ao que interpreta esses signos e realiza o exame oracular, e digo "Observa para mim as vísceras, o que elas significam para mim". (21) Tendo-as tomado e lido ${ }^{98}$, ele interpreta que:

${ }^{85}$ Metretika.

${ }^{86}$ Statika.

${ }^{87}$ Xenofonte, Memoráveis 4.5.12; 4.6.7.

${ }^{88}$ Arriano inspirou-se nessas linhas para escrever o capítulo 49 do Encheiridion.

${ }^{89}$ Noesai to boulema tes physeos. "Propósito" é nossa tradução para boulema.

${ }^{90} \mathrm{O}$ verbo aqui é parakoloutheo, literalmente "seguir ou observar de perto" e que temos traduzido por "compreender". De fato, Dobbin e Georg Long traduzem o termo por "understand". Porém, a ocorrência do verbo logo abaixo relacionado ao termo physis indica que Epicteto, aqui, joga com os dois sentidos do verbo: "seguir algo" e "seguir com a razão" ("compreender").

${ }^{91} \mathrm{O}$ verbo aqui é hamartano ("cometer faltas").

${ }^{92}$ Katorthoun: infinitivo aoristo de katorthoo, que significa literalmente "estar ereto". Aqui, vemos Epicteto opondo esse verbo a hamartano ("cometer faltas").

${ }_{93}$ É como traduzimos o verbo epizeteo.

94 Rhomaisti: a frase indica que Epicteto tem como interlocutores (e alunos) jovens romanos.

${ }^{95} \mathrm{Cf}$. nota cima sobre parakoloutheo.

96 Thytes: aquele que perfaz o sacrifício, o adivinho.

${ }^{97} \mathrm{Cf}$. Xenofonte, Memoráveis, 1.1.3.

98 Anaptyxas: particípio aoristo de anaptysso, literalmente "desenrolar um rolo de pergaminho", donde "ler". 
"Homem, tens a capacidade de escolha por natureza desimpedida e não constrangida, é isso que está escrito aí nas vísceras. (22) Demonstrar-teei isso primeiro sobre o tópico do assentimento. Pode alguém te impedir de inclinar-te para a verdade? Ninguém pode. Pode alguém te constranger a aceitar o falso? Ninguém pode. (23) Vês que, nesse mesmo tópico, possuis a capacidade de escolha ${ }^{99}$ desimpedida, não constrangida, desembaraçada? (24) Vejamos: é diferente em relação à capacidade do desejo e à capacidade do impulso? Então o que pode vencer um impulso senão outro impulso? O que <pode vencer> o desejo e a repulsa senão outro desejo e outra repulsa?"100

(25) - Se - diz <um presente> - alguém me impuser o medo da morte, ele me constrangerá.

- <Constrangerá> não o que impõe <o medo da morte>, mas <constrangerás a ti mesmo> porque te parece melhor fazer alguma dessas coisas que morrer. (26) Assim, ao contrário, é a tua opinião que te constrange - isto é, a escolha constrange a escolha ${ }^{101}$. (27) Pois se Deus nos desse essa parte peculiar, tomando-a de si mesmo, tornando-a impedida e constrangida por ele ou por algum outro, não mais seria Deus, nem cuidaria de nós do modo que é preciso.

(28) "Essas coisas descubro - diz <o sacerdote oracular> - nos animais sacrificados ${ }^{102}$. Esses são os signos enviados a ti. Se quiseres, és livre. Se quiseres, não censurarás ninguém, não acusarás ninguém, todas as coisas estarão segundo a inteligência, tanto a tua quanto a de Deus".

(29) Em razão desse mesmo oráculo, vou ao sacerdote oracular e ao filósofo, não os admirando em razão da interpretação, mas <admirando> as coisas mesmas que foram interpretadas.

\section{Diatribe 1.21 - A respeito dos que desejam ser admirados:}

(1) Quando alguém possui a posição que é preciso ter na vida, não fica embasbacado ${ }^{103} \mathrm{com}$ as coisas exteriores. (2) Homem, o que desejas que ocorra para ti? Eu me contento se eu desejar e repudiar segundo a natureza; se me servir do impulso e da repulsa segundo a natureza; e o mesmo quanto à intenção ${ }^{104}$, ao propósito, ao assentimento. Então por que andas de lá para cá diante de nós como se tivesses engolido uma espada ${ }^{105}$ ?

- (3) Desejo que os que me encontrem me admirem e, seguindo-me,

\footnotetext{
${ }^{99}$ To proairetikon.

${ }^{100}$ Portanto, os três tópicos - escolha (prohairesis), desejo ou repulsa (orexis ou ekklisis) e impulso (horme) — são cobertos, demonstrando-se que funcionam de modo desimpedido.

${ }^{101}$ Cf. Diss. 4.1.68.

${ }^{102}$ Ta hiera.

${ }^{103} \mathrm{O}$ verbo aqui é chasko, que significa literalmente "abrir a boca".

${ }^{104}$ Prosthesis: intenção, aplicação. Esta é a única ocorrência desse termo em Epicteto.

105 O termo é obeliskos, literalmente "espeto". Epicteto quer com isso indicar que o indivíduo anda altivo. Cf. Ench. 22; 46.1; 49.
} 
exclamem: "O grande filósofo!"

(4) Quem são estes que queres que te admirem? Não são aqueles sobre os quais costumas dizer que estão loucos? Queres ser admirado pelos loucos?

\section{Diatribe 1.22 - Sobre as pré-noções ${ }^{106}$ :}

(1) Pré-noções são comuns a todos os homens. E uma pré-noção não entra em conflito com outra pré-noção. Pois quem entre nós não afirma que o bem é vantajoso e $\langle\ldots .\rangle^{107}$ preferível ${ }^{108}$ ? E que é preciso em todas as circunstâncias procurá-lo e buscá-lo? Quem entre nós não afirma que o justo é bom e adequado? Então quando ocorre o conflito? (2) Quando se faz o ajuste $^{109}$ das pré-noções às substâncias particulares. (3) Se alguém disser "Agiu belamente, é um homem corajoso", <e outro replicar que> "Estava, porém, fora de si!", neste momento ocorre o conflito dos homens uns com os outros. (4) Este é o conflito entre os judeus, os sírios, os egípcios e os romanos - não acerca de que é preciso reverenciar o que é sancionado pelos Deuses ${ }^{110}$ acima de todas as coisas e buscá-lo em toda circunstância, mas se é sancionado ou não pelos Deuses comer carne de porco ${ }^{111}$. (5) Encontrareis esse mesmo conflito entre Agamenon e Aquiles ${ }^{12}$. Chama-os para estarem entre nós. belamente?

- Que dizes tu, Agamenon? Não é bom fazer o que é preciso e agir

- Certamente!

- (6) O que dizes, Aquiles? Não te agrada agir belamente?

- A mim, sobretudo, entre todas as coisas, agrada.

Ajustai, pois, as pré-noções. (7) Aí começa o conflito. Um diz "Não há precisão de restituir Criseis ${ }^{13}$ ao seu pai", mas o outro diz "É claro que é preciso". Evidente que um deles aplica erradamente a pré-noção do que é preciso. (8) Em seguida, o primeiro diz: "Se me é preciso restituir Criseis, me é preciso tomar o prêmio de algum de vós". E o segundo diz: "Então é preciso que tomes a minha amada?" "Sim, a tua amada", diz o primeiro. "E

\footnotetext{
${ }^{106}$ Prolepseon: gentivo plural de prolepsis. Cf. Diss. 1.2.6 e nota.

${ }^{107}$ Lacuna do códice.

${ }^{108}$ Haireton: adjetivo verbal de haireo (escolher).

${ }^{109}$ Epharmoge.

110 "Sancionado pelos Deuses" é nossa tradução para hosios.

${ }^{111}$ Epicteto mencionara esse conflito de opiniões acerca do que é pio em Diss. 1.11.12 ss. Quanto à verdadeira piedade, cf. Diss. 1.13.

${ }^{112}$ Cf. Horácio, Epístolas, 1.2.

113 Filha de Crisis, sacerdotisa de Apolo. Criseis significa literalmente "filha de Apolo", tendo recebido mais tarde o nome de Astínome. Segundo a Ilíada (1.392), Agamenon a teria capturado e escravizado. Agamenon, porém, é levado a devolvê-la graças a uma praga de Apolo que recai sobre o exército grego. Agamenon, após isso, toma Briseida, lote de Aquiles, que se ofende muitíssimo com o fato.
} 
só eu perderei o meu prêmio?" Assim começa o conflito.

(9) O que é instruir-se? Aprender a ajustar as pré-noções naturais às substâncias particulares de modo adequado à natureza e, além disso, distinguir, entre as coisas, as que são encargo nosso e as que não são. (10) Sob nosso encargo estão a capacidade de escolha e todas as obras que envolvem a capacidade de escolha. Não sob nosso encargo estão o corpo, as partes do corpo, as posses, os pais, os irmãos, os filhos, a pátria - em suma: as coisas que nos acompanham ${ }^{114}$. (11) Mas onde colocamos o bem? A que substância o aplicamos? À que é encargo nosso?

- (12) Então não é um bem a saúde, a boa proporção do corpo, a vida? Nem os pais, nem os filhos, nem a pátria?

- E quem irá te suportar <se sustentares tal opinião>?

- (13) Transfiramos, agora, <a denominação "bem”> para essas coisas aí. É possível ser feliz ao ser lesado e perdê-las?

- Não é possível.

- E, em relação às coisas que nos acompanham, é preciso $\langle\ldots\rangle^{115}$ tal comportamento $^{116}$. E como é possível? Pois eu <tendo> por natureza para o que me é vantajoso. (14) Se me é vantajoso possuir terra arável, me é vantajoso tomá-la do vizinho. Se me é vantajoso possuir uma toga, me é vantajoso roubá-la da sala de banho. Aí <nascem> as guerras, as querelas, os tiranos, os complôs. (15) Como ainda poderei fazer o que é conveniente a Zeus? Pois se sou lesado e não-afortunado, Zeus não se importa comigo. Em seguida: "Quem é ele para mim se deseja que eu esteja nas condições em que me encontro?"117 Logo começo a odiá-lo. (16) Então por que fazemos templos? Por que fazemos estátuas em honra aos Deuses ${ }^{118}$, como se fossem para gênios malignos, como se fossem para o deus da febre? E como ainda Zeus será o libertador, o que envia as chuvas, o que dá os frutos? Se aí pusermos a substância do bem, certamente todas essas coisas resultam.

(17) Assim, o que faremos? Essa é a busca de quem filosofa pelo que é <real> e está partejando <a verdade ${ }^{119}$. Agora, eu não vejo o que é o bem e o mal. Estou louco? (18) Porém, se ponho o bem aí onde estão as coisas

\footnotetext{
${ }^{114}$ Koinonoi: literalmente "os companheiros".

${ }^{115}$ Outra lacuna.

${ }^{116}$ Há uma lacuna aqui. Optamos por nada acrescentar, mas somente verter as palavras disponíveis.

117 Seguimos o texto quase ao pé da letra. Alguns tradutores efetuam paráfrase dessas frases, buscando apurar o sentido. Georg Long, por exemplo, verte a passagem assim: "for if I sustain damage and am unlucky, he takes no care of me; and what is he to me if he cannot help me; and further, what is he to me if he allows me to be in the condition in which I am?"

${ }_{118}$ Agalmata: acusativo plural de agalma.

${ }^{119}$ Seguimos as conjecturas de Dobbin e Souilhé. Georg Long traduz (e Oldfather o segue) a frase por "This is the inquiry of the true philosopher who is in labour", observando que a passagem remete a Teeteto $150-1$.
} 
que são passíveis de escolha, todos rirão de mim! Algum ancião grisalho, usando muitos anéis de ouro, chegará. Então, balançando a cabeça, dirá: "Escuta, filho, é preciso filosofar, mas é preciso também ter cérebro" ${ }^{120}$. Essas coisas são tolices! (19) Tu aprendes silogismos dos filósofos, mas sabes melhor que eles o que é preciso fazer". (20) "Homem, por que me repreendes, se sei?" (21) O que digo para esse prisioneiro? Se eu silencio, ele explode. Que é preciso dizer senão "Perdoa-me como àqueles que amas. Estou fora de $\operatorname{mim}^{121}$ ! Estou louco!"

\section{Diatribe 1.27 - De quantos tipos são as representações e quais auxílios é preciso ter dispostos à mão em relação a elas:}

(1) As representações nos advêm de quatro modos: pois ou é algo e assim se afigura, ou não é nem se afigura como o que é, ou é e não se afigura, ou não é e se afigura ${ }^{122}$. (2) De resto, é obra do homem instruído acertar o alvo $^{123}$ em todas essas coisas. Qualquer aflição ${ }^{124}$ que haja, é preciso aplicar sobre ela o remédio ${ }^{125}$. Se os sofismas dos pirrônicos e dos acadêmicos nos afligem, sobre eles apliquemos o remédio. (3) Se o caráter persuasivo $^{126}$ das coisas, segundo o qual algumas coisas nos afiguram boas não o sendo, aí busquemos o remédio. Se o hábito ${ }^{127}$ nos aflige, é preciso tentar achar um remédio para ele. (4) Então qual medicamento ${ }^{128}$ há para descobrir quanto ao hábito? O hábito contrário. (5) Ouves quando os homens comuns ${ }^{129}$ dizem "Infeliz, morreu! O pai e a mãe estão em profundo pesar $^{130}$, tombou, mas <estava> na flor da idade ${ }^{131}$, e no estrangeiro!” (6) Ouve as palavras contrárias e te afasta daquelas vozes, opõe tu ao hábito o

\footnotetext{
${ }^{120}$ Dei kai enkephalou echein. Poderíamos traduzir também por: "É preciso ter miolos!"

${ }^{121}$ Ouk eimi emautou: literalmente "Não sou de mim mesmo". Em grego, há uma expressão semelhante: En emautou einai ("Sou senhor de mim mesmo").

122“O que se afigura" é nossa tradução para to phainomenon. Assim, Epicteto distingue, na representação, aquilo que ela representa ("é de" ou "não é de") e nosso parecer sobre o que ela representa. Assim, no primeiro e no segundo casos temos representações compreensivas, nas quais nosso juízo (o que se afigura) está de acordo com o que é e o que não é; no terceiro e quarto casos, temos representações não compreensivas, nas quais nosso juízo (o que se afigura) não está de acordo com o que é e o que não é.

${ }^{123} \mathrm{O}$ verbo aqui é eustocheo.

${ }^{124}$ Thlibon: este termo só ocorre em Epicteto aqui e na linha adiante.

${ }^{125}$ Boetheia: este termo só ocorre em Epicteto aqui e nas linhas adiante.

${ }^{126}$ Pithanotetes: nominativo plural de pithanotes.

${ }^{127}$ Ethos.

${ }^{128}$ Boetema.

${ }^{129}$ Idioton: genitivo plural de idiotes, termo que designa, em Epicteto, o homem comum ou o homem sem instrução filosófica.

${ }^{130}$ Seguimos aqui Georg Long, que observa que apoleto $\left(3^{\mathrm{a}}\right.$. do singular do indicativo aoristo médio de appolymi) significa aqui não "morreu", mas "está em profundo pesar". Cf. Eurípedes, Alcestes, 825.

${ }^{131}$ Aoros: literalmente "imaturo".
} 
hábito contrário. Contra os argumentos sofísticos, <opõe tu> a lógica, o exercício nessas questões e a prática. Contra o caráter persuasivo das coisas, é preciso ter pré-noçõos ${ }^{132}$ claras $^{133}$, polidas $^{134}$ e à mão.

(7) Quando a morte se afigurar como um mal, <é preciso> ter à mão que convém evitar as coisas más e que a morte é necessária. (8) Pois o que farei? Aonde ir para fugir dela? Que eu seja Sarpedão ${ }^{135}$, filho de Zeus, para que fale nobremente assim:

"Se eu for, ou quero ser o melhor, ou <quero> conceder a outro a ocasião ${ }^{136}$ para ser o melhor. Se não puder eu mesmo ser bem-sucedido, não invejarei alguém por fazer algo nobre" ${ }^{\text {"137. }}$.

Que < agir assim> esteja acima de nós; não nos seria acessível <crer> no seguinte?

(9) "Aonde ir para fugir da morte? Indicai-me o país, indicai-me os povos para os quais eu vá, de onde ela não se aproxime, indicai-me a fórmula mágica ${ }^{138}$. Senão, o que quereis que eu faça? Não posso escapar da morte. (10) Mas não posso escapar de temê-la e morrerei lamentando e tremendo?"

Pois essa é a origem do sofrimento ${ }^{139}$ : querer algo e não obter ${ }^{140}$. (11) Donde, se puder, por um lado, modificar as coisas externas segundo o meu querer ${ }^{141}$, modifico-as; se não, por outro lado, desejo cegar quem me impede. (12) Pois por natureza o homem não suporta ser separado do bem, não suporta deparar-se com o mal ${ }^{142}$. (13) Assim, por fim, quando nem modificar as coisas nem cegar quem me impede eu puder, <então> sento e gemo e ofendo quem o pode - Zeus e os demais Deuses. Pois se não se importam comigo, o que eles são para mim $^{143}$ ?

- (14) Sim, mas serás ímpio!

- O que para mim será pior do que é agora? Em suma, lembra-te disto, se a piedade e o vantajoso não estiverem juntos, não se pode

\footnotetext{
${ }^{132}$ Prolepsis: conceito estoico que pode ser traduzido por "pré-noção" ou "pré-concepção". Não se trata propriamente de um conceito inato, mas a tendência que temos para buscar a formulação de certos conceitos, a urgência de nossa própria natureza para que formemos certas noções, como, por exemplo, a de justiça. Cf. DL 7; D 4.8.6; Cícero, Tópica, 7; De Natura Deorum, 1.16; Questões tusculanas, 1.24; De Finibus, 3.6.

${ }^{133}$ Enarges.

${ }^{134} \mathrm{O}$ termo aqui é esmegmenas, particípio de smecho ("limpar"), donde "lustradas", "polidas".

${ }^{135}$ Filho de Zeus com Europa.

136“Ocasião" aqui traduz aphorme.

${ }^{137} \mathrm{Cf}$. Homero, Ilíada, 12.5.328.

${ }^{138}$ Epaiode: jônico e poético de epoide.

${ }^{139}$ Pathos.

${ }^{140}$ Thelein ti kai me ginesthai.

${ }^{141}$ "Meu querer" aqui traduz boulesis, termo derivado verbo bouleo (querer) que só ocorre em Epicteto duas vezes: aqui e em D 2.1.4.7.3.

${ }^{142}$ Cf. Ench. 33.1.

${ }^{143}$ Cf. Ench. 33.4.
} 
conservar a piedade em si. Não te parecem essas coisas importantes?

(15) Que venham e nos encontrem o pirrônico e o acadêmico. Eu, com efeito, por minha parte, não tenho tempo livre para essas coisas, nem posso defender o senso comum ${ }^{144}$. (16) Se também eu tivesse uma demanda sobre um diminuto terreno ${ }^{145}$, requereria outro para ser meu advogado. Então com o que me satisfaço nesse tópico? (17) Como acontece a percepção, <se> primeiro através do todo ou da parte, <sobre isso> talvez eu não saiba argumentar, ambas <as possibilidades> me confundem. Entretanto, que eu e tu não sejamos a mesma pessoa, eu sei muitíssimo bem. (18) Como isso? Quando quero engolir um pedaço de pão ${ }^{146}$, jamais o ponho ai ${ }^{147}$, mas aqui ${ }^{148}$. Quando quero pegar um pão ${ }^{149}$, jamais pego a vassoura $^{150}$, mas sempre vou em direção ao pão como que para um alvo. (19) Vós mesmos, que suprimis as percepções, fazeis algo diferente ${ }^{151}$ ? Qual de vós vai ao moinho quando quer ir ao banho público?

- (20) E então? Não é preciso agarrar-se a estas coisas na medida de nossa capacidade: velar pelo senso comum ${ }^{152}$, fortificar-nos contra o que é contra ele? ${ }^{153}$

- (21) E quem diz o contrário? Porém, <ocupa-se disso> quem tem capacidade e tempo livre. Aquele que treme, que se agita e que tem o coração feito em pedaços ${ }^{154}$ precisa ter tempo ${ }^{155}$ para outra coisa.

\footnotetext{
${ }^{144}$ Synetheia.

${ }^{145}$ Agridion: diminutivo de agros ("terreno").

${ }^{146}$ Psomos: literalmente "naco" de algum alimento. Pusemos "de pão" para harmonizar com a frase seguinte.

${ }^{147}$ Indicando a boca do interlocutor.

${ }^{148}$ Indicando a própria boca.

${ }^{149}$ Artos.

${ }^{150}$ Saron.

${ }^{151}$ Epicteto dirige-se aqui aos céticos pirrônicos, que pretendem suspender o juízo sobre todas as coisas.

${ }^{152}$ Synetheia.

${ }^{153}$ Aqui Epicteto dá vida a uma possível declaração de um cético.

${ }^{154} \mathrm{O}$ verbo aqui é rhegnumi.

${ }^{155} \mathrm{O}$ verbo aqui é proseukaireo.
} 


\section{Referências bibliográficas:}

ARISTÓTELES. Nicomachean Ethics. Trad. Rackham. Harvard: Loeb, 1926.

ARISTÓTELES. Nicomachean Ethics. Trad. Rackham. Harvard: Loeb, 1926.

AULO GÉLIO. Noctium Atticarum. Harvard, Loeb, 2002.

BRAICOVICH, R. Epicteto necessita de Zeus? Gratitud, vergüenza y responsabilidade moral em Epicteto. IN: Elenchos, 2012, 33, vol. 1, p. 115 133, Roma.

CÍCERO. On the Nature of the Gods. Academics. Trad. H. Rackham. Harvard: Loeb Classical Library, 1933.

CÍCERO. Tusculan Disputations. Trad. J. E. King. Harvard: Loeb Classical Library, 1927.

CÍCERO. Topica. Trad. Hugh Tredennick \& E. S. Forster. Harvard: Loeb Classical Library, 1930.

CÍCERO. On the orator. On fate. Stoic Paradoxes. Divisions of oratory. Trad. H. Rackham. Harvard: Loeb Classical Library, 1942.

CÍCERO. De Finibus. Bonorum Et Malorum. Trad. H. Rackham. Harvard: Loeb Classical Library, 1914.

DINUCCI, A.; JULIEN, A. Epicteto: testemunhos e fragmentos. São Cristóvão: EdiUFS, 2009.

DINUCCI, A; BRITO, R. Tradução e Apresentação da Diatribe de Epicteto 1.5. IN: Revista de Filosofia Antiga (USP. Ed. português), v. 8, p. 116, 2014.

DIÓGENES LAÉRCIO. Lives of Eminent Philosophers, vol. I, II. Trad. R. D. Hicks. Harvard: Loeb Classical Library, 1925.

EPICTETO. Entretiens; Livre I. Trad. Souilhé. Paris: Les Belles Lettres, 1962.

EPICTETO. Epictetus: Discourses, Book 1. Trad. Dobbin. Oxford: Clarendon, 2008.

EPICTETO. O Encheirídion de Epicteto. Edição Bilíngue. Trad. Aldo Dinucci; Alfredo Julien. São Cristóvão: EdiUFS, 2012.

EPICTETO. The Discourses as reported by Arrian (Books I, II, III \& IV); Fragments; Encheiridion. Trad. W. A. Oldfather. Cambridge: Loeb, 2000.

EPICTETO. The Discourses of Epictetus as reported by Arrian (Books I, II, III \& IV);Fragments; Encheiridion. Trad. W. A. Oldfather. Cambridge: Loeb, 2000.

EPICTETO. The Discourses of Epictetus, with the Enchiridion and Fragments. Trad. George Long. Londres: George Bell \& Sons, 1877.

EURIPIDES. Cyclops, Alcestis, Medea. Trad. David Kovacs. Trad. J. H. Leonard. Harvard: Loeb, 1995.

HOMERO. Odissey, vol. I, II. Trad. Dimock and A. T. Murray. Harvard: Loeb Classical Library, 1995. 
HOMERO. OIliad, vol. I, II. Trad. A. T. Murray. Harvard: Loeb Classical Library, 1927.

HORÁCIO. Satires, Epistles, Ars Poetica. Trad. H. R. Fairclough. Harvard: Loeb, 1926.

LACTÂNCIO. De falsa religione. Textkritisches zum 1. Buch der Diuinae institutiones,' Y. LEHMANN; G. FREYBURGER; J. HIRSTEIN (ed). Antiquité tardive et humanisme: de Tertullien à Beatus Rhenanus. Mélanges offerts à François HEIM à l'occasion de son 70e anniversaire. Turnhout, 2005.

MARCOS AURÉLIO ANTONINO. Marcus Aurelius. Trad. C. R. Haines. Harvard: Loeb Classical Library, 1916.

PLATÃO. Theaetetus, Sophist. Trad. H. N. Fowler. Harvard: Loeb Classical Library, 1988.

SCHENKL. Epicteti dissertationes ab Arrianos digestae. Lipsia: Teubner, 1916.

SCHWEIGHAUSER. Epicteteae Philosophiae Monumenta. 3 vol. Leipsig: Weidmann, 1799.

SÊNECA. Epistles 1-66. Trad. R. M. Gummere. Harvard: Loeb Classical Library, 2001.

SÊNECA. Epistles 66-92. Trad. R. M. Gummere. Harvard: Loeb Classical Library, 2001.

SÊNECA. Moral Essays, vol. II. Trad. J. W. Basore. Harvard: Loeb Classical Library, 2001.

SÊNECA. Moral Essays, vol. III. Trad. J. W. Basore. Harvard: Loeb Classical Library, 2001.

SEXTO EMPÍRICO. Against the Professors. Trad. R. G. Bury. Harvard: Loeb Classical Library, 1949.

SEXTO EMPÍRICO. Outlines of Pyrrhonism. Trad. R. G. Bury. Harvard: Loeb Classical Library, 1933.

SUETÔNIO. Lifes of the Caesars volumes I \& II. Trad. Rolfe, J. C. A. Harvard, Loeb, 1914.

VON ARNIM, H. Stoicorum Veterum Fragmenta vol. 1: Zeno or Zenonis Discipuli. Berlim: De Gruyter, 2005.

VON ARNIM, H. Stoicorum Veterum Fragmenta vol. 2: Chrysippi Fragmenta Logica et Physica. Berlim: De Gruyter, 2005.

VON ARNIM, H. Stoicorum Veterum Fragmenta vol. 3: Chrysippi fragmenta moralia. Fragmenta Successorum Chrysippi. Berlim: De Gruyter, 2005.

XENOFONTE. Memorabilia. Oeconomicus. Symposium. Apology. Trad. E. C. Marchant; O. J. Todd. Harvard: Loeb Classical Library, 1923. 